\title{
Meningkatkan Aktivitas dan Prestasi Belajar Siswa melalui Penerapan Model PAIKEM Kelas VIII SMPN 1 Kediri pada Materi Pokok Kubus dan Balok Tahun Pelajaran 2010/2011
}

\author{
Sahnan \\ SMPN 1 Kediri, Lombok Barat, Indonesia \\ *Coresponding Author: sahnan88@gmail.com
}

\begin{abstract}
Abstrak: Kurangnya pemahaman siswa terhadap materi yang disampaikan oleh guru berakibat pada rendahnya Prestasi belajar matematika siswa, salah satu penyebab dari masalah ini adalah kurang tepatnya pendekatan atau metode yang digunakan dalam proses belajar mengajar matematika. Tujuan Penelitian ini adalah Mengetahui Penerapan Pembelajaran Berbasis PAIKEM untuk Meningkatkan Aktifitas dan Prestasi belajar matematika Siswa Kelas VIII SMPN 1 Kediri Tahun Pelajaran 2010/2011. Jenis penelitian ini merupakan Penelitian Tindakan Kelas (PTK) yang dilakukan dalam dua siklus. Data aktivitas belajar siswa diambil dengan menggunakan lembar observasi, sedangkan data Prestasi belajar siswa diperoleh melalui tes yang diberikan pada tiap akhir siklus. Data hasil pengamatan dianalisis dengan menggunakan rumus persentase dan rumus ketuntasan klasikal. Hasil penelitian menunjukan bahwa aktivitas belajar siswa pada siklus I sebesar $56 \%$ tergolong dalam kategori cukup aktif dan pada siklus II sebesar $88 \%$ tergolong dalam kategori sangat aktif. Sedangkan data Prestasi belajar siswa pada siklus I, dengan ketuntasan yang diperoleh sebesar $25 \%$, artinya bahwa belum tuntas dan pada siklus II memperoleh ketuntasan sebesar $86 \%$ dengan kategori tuntas. Berdasarkan hasil tersebut dapat disimpulkan bahwa penerapan pembelajaran berbasis PAIKEM dapat meningkatkan aktivitas dan Prestasi belajar IPA pada siswa kelas VIII SMPN 1 Kediri Tahun Pelajaran 2010/2011.
\end{abstract}

Kata Kunci: PAIKEM; aktivitas belajar; Prestasi belajar matematika

\section{PENDAHULUAN}

Suatu pengajaran yang hanya mengutamakan prinsip individual tidak akan menguntungkan siswa maupun masyarakat. Kehidupan sebagian besar siswa dipengaruhi oleh orang lain maupun teman-temannya. Dimana ada orang hidup bersama-sama, tentu disana ada kontak sosial. Hubungan sosial antara sesama manusia merupakan suatu keharusan, sebab dengan kontak sosial orang akan dapat mengembangkan kepribadiannya dengan lebih sempurna. Dengan kegiatan-kegiatan ini maka dalam setiap kegiatan mengajar guru dituntut agar sanggup menciptakan suasana sosial yang membangkitkan kerja sama diantara para siswa dalam mewujudkan materi pelajaran supaya dapat diserap lebih efektif dan efesien (Depdiknas, 2003).

Proses belajar mengajar pada intinya tertumpu pada suatu persoalan yaitu bagaimana guru melibatkan siswa agar terjadi proses belajar yang efektif untuk mencapai hasil sesuai dengan tujuan. Hal ini menuntut guru untuk lebih kreatif memilih metode pembelajaran yang sesuai dengan materi pelajaran yang akan disajikan kepada siswa.

Pada proses pembelajaran Matematika selama ini guru lebih mendominasi proses pembelajaran yaitu guru menyampaikan materi dengan metode ceramah sedangkan siswa hanya mendengar, mencatat dan mengerjakan soal yang diberikan oleh guru. Pembelajaran seperti ini akan mematikan kreatifitas siswa sehingga berdampak pada rendahnya prestasi belajar siswa. 
Informasi yang diperoleh dari hasil wawancara dengan guru Matematika SMPN 1 Kediri bahwa aktifitas siswa dalam mengikuti pelajaran masih rendah, walaupun ada sebagian kecil siswa yang aktif dan menanggapi apa yang disampaikan oleh guru. Kegiatan pembelajaran masih berpusat pada guru sehingga siswa kurang memiliki kesempatan untuk mengembangkan sendiri konsep-konsep Matematika yang ada. Hal ini menyebabkan pelajaran Matematika kurang menarik sehingga mengurangi antusias siswa untuk belajar Matematika yang berdampak pada rendahnya prestasi belajar siswa.

Tabel 1. Persentase Ketuntasan Belajar Siswa Kelas VIII SMPN 1 Kediri Tahun Pelajaran 2010/2011.

\begin{tabular}{|c|l|c|c|c|c|}
\hline No & Kelas & Jumlah siswa & $\begin{array}{c}\text { Jumlah siswa } \\
\text { yang tuntas } \\
(\text { Nilai } \geq 70)\end{array}$ & $\begin{array}{c}\text { Jumlah } \\
\text { siswa yang } \\
\text { tidak tuntas } \\
(\text { Nilai } \leq 70)\end{array}$ & $\begin{array}{c}\text { Ketuntasan } \\
\text { klasikal }\end{array}$ \\
\hline 1 & VIII.1 & 33 & 25 & 8 & $74 \%$ \\
\hline 2 & VIII.2 & 36 & 23 & 13 & $62 \%$ \\
\hline 3 & VIII.3 & 35 & 26 & 11 & $69 \%$ \\
\hline 4 & VIII.4 & 35 & 20 & 19 & $47 \%$ \\
\hline
\end{tabular}

Dari data di atas diketahui bahwa ketuntasan belajar siswa masih rendah, oleh karena itu perlu mendapatkan perhatian yang serius. Untuk itu dalam penelitian tindakan kelas ini dicoba menerapkan model model PAIKEM dalam rangka meningkatkan aktivitas dan Prestasi Belajar Matematika pada siswa kelas VIII SMPN 1 Kediri Tahun Pelajaran 2010/2011. PAIKEM sebagai upaya menciptakan sistem lingkungan belajar yang memberi peluang murid terlibat secara aktif (fisik, intelektual dan atau emosional).

Mengembangkan kreatifitas dan menyenangkan (menggairahkan untuk belajar) serta dapat mewujudkan pembelajaran (intrukionaldan pengiring) secara optimal. Seperti telah dikemukakan bahwa belajar itu pada perinsipnya selalu bermakna ada keaktifan, sehingga yang diupayakan dalam PAIKEM adalah mengoptimalkan keaktifan murid itu.

Model model PAIKEM merupakan model pembelajaran dengan siswa belajar Aktif, Inovatif, Kreatif, Efektif dan Menyenangkan yang memiliki kemampuan heterogen. Model ini selalu mengusahakan agar siswa teribat dalam masalah-masalah yang dibahas selama pembelajaran.

Berdasarkan uraian diatas, untuk mengatasi permasalahan tersebut dalam pembelajaran Matematika, peneliti bekerjasama dengan guru Matematika kelas VIII.4 SMPN 1 Kediri mencoba menerapkan Model Model PAIKEM untuk Meningkatkan Aktivitas dan Prestasi Belajar Matematika pokok bahasan kubus dan balok pada Siswa Kelas VIII SMPN 1 Kediri Tahun Pelajaran 2010/2011

\section{KAJIAN TEORI}

\section{Pengertian belajar}

Usaha pemahaman mengenai makna belajar ini akan diawali dengan mengemukakan beberapa definisi tentang belajar. Cronbach dalam Sardiman (2010: 20) mengatakan bahwa "Learning is shown by a change in behavior as a result of 
experience" ini mengandung makna bahwa belajar adalah proses perubahan tingkah laku. Menurut Harold Spears dalam Sardiman (2010:20) memberikan definisi "Learning is to observe, to read, to imitate, to tri something themselves, to listen, to fallow direction" Yang berarti bahwa belajar itu adalah mengamati, membaca, meniru, mencoba sesuatu, mendengar, dan mengikuti petunjuk. Lebih lanjut menurut Geoch dalam Sardiman (2010: 20), mengatakan bahwa "Lerning is a change in performance as a result of practice". Yang artinya belajar adalah sebuah perubahan kemampuan sebagai hasil dari sebuah praktik.

Definisi yang diungkapkan di atas, maka dapat disimpulkan bahwa belajar itu senantiasa merupakan perubahan tingkah laku atau penampilan, dengan serangkaian kegiatan minsalnyadengan membaca, mengamati, mendengarkan, meniru dan lain sebagainya. Juga belajar itu akan lebih baik, kalau si subjek belajar itu mengalami atau melakukannya, jadi tidak bersifat verbalistik.

Dalam pengertian luas, belajar dapat diartikan sebagai kegiatan psiko-fisik menuju ke perkembangan pribadi seutuhnya. Kemudian dalam arti sempit, belajar dimaksudkan sebagai usaha penguasaan materi ilmu pengetahuan yang merupakan sebagian kegiatan menuju terbentuknya kepribadian seutuhnya.

Ada yang mendifinisikan belajar adalah "berubah". dalam hal ini yang dimaksud belajar berarti usaha mengubah tingkah laku. Jadi belajar akan membawa suatu perubahan pada individu-individu yang belajar. Perubahan tingkah hanya berkautan dengan penambahan ilmu pengetahua, tetapi juga berbentuk kecakapan, keterampilan, sikap, pengertian, harga diri, minat, watak, penyusaian diri. Dengan demikian, dapatlah dikatakan bahwa belajar itu sebagai rangkaian kegiatan jiwa raga, psiko-fisik untuk menuju ke perkembangan pribadi manusia seutuhnya, yang berarti menyangkut unsur cipta, rasa dan karsa, ranah kognitif, efektif, dan psikomotor (Sadirman, 2010: 21).

Menururut Bruner dalam Nasution (2010: 10), proses belajar dapat dibedakan tiga fase atau episode, yaitu informasi, tranformasi,dan evaluasi.

a. Informasi, dalam tiap pelajaran diperoleh sejumlah informasi, ada yang menambah pengetahuan yang telah dimiliki, ada yang memperhalus dan yang memperdalamnya dan ada pula yang bertentangan dengan apa yang telah diketahui sebelumnya.

b. Transformasi, informasi itu harus dianalisis, diubah atau ditranspormasi ke dalam bentuk yang lebih abstrak atau konseptual agar dapat digunakan untuk hal-hal yang lebih luas.

c. Evaluasi, kemudian dinilai hingga manakah pengetahuan yang diperoleh dan transformasi itu dapat dimanfaatkan untuk memahamigejala-gejala lain.

Ketiga fase ini selalu terdapat dalam proses belajar. Yang menjadi masalah ialah berapa banyak informasi diperlukan agar dapat ditransformasi.

Tujuan belajar sebenarnya sangat banyak dan bervariasi, ditinjau secara umum, tujuan belajar itu ada tiga jenis (Sadirman, 2010: 25-27), yaitu:

a. Untuk Mendapatkan Pengetahuan

Hal ini ditandai dengan kemampuan berpikir. Pemilikan pengetahuan dan kemampuan berpikir sebagai yang tidak dapat dipisahkan. Dengan kata lain, tidak dapat mengembangkan kemampuan berpikir tanpa bahan pengetahuan, sebaliknya kemampuan berpikir akan memperkaya pengetahuan. Tujuan inilah yang memiliki 
kecendrungan lebih besar perkembangannya di dalam kegiatan belajar. Dalam hal ini peranan guru sebagai pengajar lebih menonjol.

b. Penanaman Konsep dan Keterampilan

Penanaman konsep atau merumuskan konsep, juga memerlukan suatu keterampilan. Keterampilan memang dapat dididik, yaitu dengan banyak melatih kemampuan. Demikian juga mengungkapkan perasaan melalui bahasa tulisan, bukan soal kosakata atau kata bahasa, semua memerlukan banyak latihan.

c. Pembentukan Sikap

Dalam menumbuhkan sikap mental, prilaku dan pribadi anak didik, guru harus lebih bijak dan hati-hati dalam pendekatanya.

Jadi pada intinya, tujuan belajar itu adalah ingin mendapatkan pengetahuan, keterampilan dan penanaman sikap mental atau nilai-nilai. Pencapaian tujuan belajar berarti akan menghasilkan Prestasi Belajara.

\section{Aktivitas belajar}

Aktivitas belajar merupakan proses aktivitas pembelajaran yang melibatkan seluruh aspek psikofisis peserta didik, baik jasmani maupun rohani sehingga akselerasi perubahan prilakunya dapat terjadi secara cepat, tepat, mudah, dan benar, baik berkaitan dengan aspek kognitif, efektif, maupun psikomotor (Hanafiah, 2009: 23).

Prinsip belajar adalah berbuat. Berbuat untuk mengubah tingkah laku, jadi melakukan kegiatan. Tidak ada belajar kalau tidak ada aktivitas. Itulah sebabnya aktivitas merupakan prinsip atau asas yang sangat penting di dalam interaksi belajarmengajar. Sebagai rasionalitasnya hal ini juga mendapatkan pengakuan dari berbagai ahli pendidikan.

Dalam dinamika kehidupan manusia, berfikir dan berbuat sebagai suatu rangkaian yang tidak dapat dipisahkan. Begitu juga dalam belajar sudah barang tentu tidak mungkin meninggalkan dua kegiatan itu, berfikir dan berbuat. Seseoarang yang telah berhenti dan berbuat perlu dilakukan eksistensi kemanusiaannya. Hal ini sekaligus merupakan hambatan bagi proses pendidikan yang bertujuan ingin memanusiakan manusia. Ilustrasi ini menunjukan penegasan bahwa dalam belajar sangat memerlukan kegiatan berfikir dan berbuat.

Menurut Paul B. Diedrich dalam Sardiman (2010: 101), jenis-jenis aktivitas belajar siswa digolongkan sebagai berikut:

a. Visual activities, yang termasuk di dalamnya misalnya, membaca, memperhatikan gambar demonstrasi, percobaan, pekerjaan orang lain.

b. Oral activities, seperti: menyatakan, merumuskan, bertanya, memberi saran, mengeluarkan pendapat, mengadakan wawancara, diskusi.

c. Listening activities, sebagai contoh mendengarkan: uraian, percakapan, diskusi, musik, pidato.

d. Writing activities, seperti misalnya menulis cerita, karangan, laporan, angket, menyalin.

e. Drawing activities, minsalnya: menggambar, membuat grafik, peta, diagram.

f. Motor activities, yang termasuk didalamnya antara lain: melakukanpercobaan, membuat konstruksi, model mereparasi, bermain, berkebun, beternak.

g. Mental activities, sebagai contoh misalnya: menanggapi, mengingat, memecahkan soal, menganalisis, melihat hubungan, mengambil keputusan. 
h. Emotional activities, seperti misalnya, menaruh minat, merasa bosan, gembira, bersemangat, bergairah, berani, tanang, gugup.

Dengan mengemukakan beberapa pandangan para ahli di atas, jelas bahwa dalam kegiatan belajar, peserta didik atau siswa harus aktif berbuat. Dengan kata lain, bahwa dalam belajar diperlukan adanya aktifitas. Tanpa aktifitas, proses belajar tidak mungkin berlangsung dengan baik.

\section{Prestasi belajar}

Prestasi belajar adalah sebuah kalimat yang terdiri dari dua kata yaitu prestasi dan belajar. Antara kata prestasi dan belajar mempunyai arti yang berbeda. Oleh karena itu, sebelum pengertian prestasi belajar, ada baiknya pembahasan ini diarahkan pada masing-masing permasalahan terlebih dahulu untuk mendapatkan pehaman lebih jauh mengenai makna kata prestsi dan belajar. Hal ini juga untuk memudahkan dalam memahami lebih mendalam tentang pengertian prestsi belajar itu sendiri.

Prestasi menurut Djamarah (1994) adalah penilaian pendidikan tentang kemajuan siswa dalam segala hal yang dipelajari di sekolah yang menyangkut pengetahuan atau kecakapan/keterampilan yang dinyatakan sesudah hasil penelitian. Penilaian tersebut dilakukan melalui evaluasi. Sedangkan menurut Sudjana (1996), mengatakan bahwa prestasi belajar adalah kemampuan yang dimiliki setelah menerima pengalaman belajar.

Dari pendapat di atas, dapat disimpulkan prestasi belajar adalah hasil atau taraf kemampuan yang telah dicapai siswa setelah mengikuti proses belajar mengajar dalam waktu tertentu baik berupa perubahan tingkah, keterampilan dan pengetahuan dan kemudian akan diukur dan dinilai yang kemudian akan diwujudkan dalam angka atau pertanyaan.

Prestasi belajar dipengaruhi oleh daya serap siswa, dimana daya serap pada umumnya dipengaruhi oleh dua faktor seperti yang dikemukakan oleh (Slameto, 2003) yaitu:

a. Faktor internal

Faktor internal adalah faktor yang timbul atau berasal dari siswa itu sendiri.

Faktor ini dapat dibagi menjadi tiga faktor yaitu :

1) Faktor jasmani meliputi faktor kesehatan dan cacat tubuh.

2) Faktor psikologi meliputi: intelegensi, perhatian, minat, bakat, motif, kematangan dan kesiapan.

3) Faktor kelelahan meliputi kelalahan jasmani dan rohani (bersifat psikis).

b. Faktor eksternal

Faktor eksternal adalah factor yang berasal dari luar diri siswa, faktor ini dibagi manjadi 3 yaitu:

1) Faktor keluarga meliputi cara orang tua mendidik, keadan ekonomi keluaraga, dan latar belakang budaya.

2) Faktor sekolah meliputi metode mengajar, kurikulum, alat pelajaran, standar pelajaran diatas ukuran, keadaan gedung, metode belajar dan tugas rumah.

3) Faktor masyarakat meliputi kegiatan siswa dalam masyarakat, teman bergaul dan bentuk kehidupan masyarakat.

\section{Pendekatan Pembelajaran PAIKEM.}


Pembelajran PAIKEM adalah pembelajaran bermakna yang dikembangkan dengan cara membantu peserta didik membangun keterkaitan antara informasi (Pengetahuan) baru dengan pengalaman (Pengetahuan lain) yang telah dimiliki dan dikuasai peserta didik. Peserta didik dibelajarkan bagai mana mereka mempelajari konsep dan bagaimana konsep tersebut dapat dipergunakan diluar kelas. Peserta didik diperkenankann bekerja secara kooperatif (Suprijono, 2011).

PAIKEM sebagai upaya menciptakan sistem lingkungan belajar yang memberi peluang murid terlibat secara aktif (fisik, intelektual dan atau emosional).

Mengembangkan kreatifitas dan menyenangkan (menggairahkan untuk belajar) serta dapat mewujudkan pembelajaran (instruksional dan pengiring) secara optimal, Seperti telah dikmukakan bahwa belajar itu pada perinsipnya selalu bermakna ada keaktifan, sehingga yang diupayakan dalam PAIKEM adalah mengoptimalkan keaktifan murid itu.

a) Aktif dimaksudkan bahwa dalam proses pembelajaran guru harus menciptakan suasana sedemikian rupa sehingga peserta didik aktif mengajukan pertanyaan, mengemukakan gagasan, dan mencari data dan informasi yang mereka perlukan untuk memecahkan masalah.

b) Inovatif maksudnya bisa manghadaptasikan diri dari model pembelajaran yang menyenangkan (learning is fun) yang merupakan kunci yang diterapkan dalam pembelajaran inovatif. .

c) Kreatif dimaksudkan agar guru menciptakan kegiatan belajar yang beragam, sehingga memenuhi berbagai tingkat kemampuan siswa.

d) Efektif, yaitu menghasilkan apa yang harus dikuasai oleh siswa setelah proses pembelajaran berlangsung, sebab pembelajaran memiliki sejumlah tujuan pembelajaran yang harus dicapai. Jika pembelajaran hanya aktif dan menyenangkan tetapi tidak efektif, maka pembelajaran tersebut tidak ubahnya seperti bermain biasa.

e) Menyenangkan adalah suasana belajar mengajar yang menyenangkan sehingga siwa memusatkan perhatiannya secara penuh pada belajar sehingga waktu curah perhatiannya tinggi.

Jadi pembelajaran PAIKEM adalah suatu metode pembelajaran yang mampu melibatkan siswa secara langsung dengan berbagai pengenalan terhadap lingkungan. Dengan demikian selama dalam proses pembelajaran akan mengajak siswa lebih aktif, inovatif, kreatif, efektif dan menyenangkan.

\section{METODE PENELITIAN}

\section{Rancangan Penelitian}

Penelitian ini adalah penelitian tindakan kelas. Proses penelitian tindakan kelas dirancang dalam bentuk siklus sesuai dengan rancangan yang ditetapkan dalam PTK (Penelitian Tindakan Kelas). Dimana setiap siklus terdiri dari 4 (empat) tahap yaitu tahap perencanaan, tahap pelaksanaan tindakan, tahap observasi dan evaluasi, dan tahap refleksi (Arikunto, 2010).

Secara rinci prosedur tindakan tiap-tiap siklus dijabarkan sebagai berikut :

\section{Siklus Pertama}
a. Perencanaan 
Perencanaan kegiatan yang dilakukan dalam pelaksanaan penerapan model PAIKEM yaitu mempersiapkan hal-hal sebagai berikut :

1) Mensosialisasikan metode pembelajaran PAIKEM pada peserta didik.

2) Menyiapkan skenario pembelajaran menggunakan metode pembelajaran PAIKEM.

3) Menyiapkan pedoman observasi untuk mencatat kegiatan belajar siswa dan kegiatan guru.

4) Membuat soal tes belajar dengan menggunakan lembar soal tes pilihan ganda.

b. Tahap Pelaksanaan

Kegiatan yang dilakukan pada tahap pelaksanaan tindakan ini yaitu: melaksanakan kegiatan belajar mengajar di kelas sesuai dengan skenario pembelajaran yang telah disusun. Skenario pembelajaran merupakan kegiatan guru dalam merencanakan kegiatan pembelajaran serta bagimana pelaksanaannya dalam kelas apakah sesuai dengan perkembangan yang akan dicapai.

c. Tahap Observasi dan Evaluasi

Kegiatan pada tahap observasi adalah melakukan observasi secara kontinyu setiap kali berlangsungnya pelaksanaan tindakan dengan mengamati pelaksanaan kegiatan belajar mengajar, apakah sesuai dengan skenario pembelajaran. Tahap evaluasi dilakukan setelah akhir setiap siklus dengan memberikan soal tes pilihan ganda untuk mengetahui ketercapaian Prestasi Belajar dengan menggunakan sistem belajar PAIKEM.

d. Tahap Refleksi

Refleksi dilakukan pada akhir siklus, pada tahap ini peneliti sebagai pengajar bersama guru yang bertindak sebagai observer mengkaji hasil yang diperoleh dari pemberian tindakan pada tiap siklus. Kegiatan pada tahap refleksi ini juga mengkaji kekurangan dan hambatan yang muncul pada saat berlangsungnya proses belajar mengajar. Sehingga diperoleh alternatif pemecahan masalah yang muncul pada setiap proses belajar mengajar sehingga dapat melakukan perbaikan untuk pelaksanaan siklus selanjutnya. Hasil refleksi pada siklus I digunakan untuk merencanakan tindakan pada siklus II dan hasil refleksi pada siklus II untuk merencanakan tindakan pada siklus ketiga.

\section{Jenis Penelitian}

Jenis penelitian yang akan digunakan adalah penelitian tindakan kelas (Classroom Action Research) karena penelitian ini juga terlibat langsung dalam proses belajar mengajar mulai dari awal sampai akhir pelajaran.

Penelitian tindakan kelas adalah suatu pencermatan terhadap kegiatan belajar berupa sebuah tindakan, yang sengaja dimunculkan dan terjadi dalam sebuah kelas secara bersama (Arikunto, 2010). Adapun rancangan yang dimaksud adalah tindakan berupa Penerapan Pembelajaran Berbasis PAIKEM Dalam Upaya Meningkatkan Aktivitas dan Prestasi Belajar Matematika pada Siswa Kelas VIII SMPN 1 Kediri Tahun Pelajaran 2010/2011.

\section{Pendekatan Penelitian}


Pendekatan adalah suatu cara yang digunakan oleh peneliti dalam suatu penelitian tentang urutan-urutan penelitian yang dilakukan (Nazir, 1999). Dalam penelitian ini pendekatan yang digunakan terbagi dalam dua jenis yaitu:

b. Pendekatan kualitatif

Pendekatan kualitatif adalah pendekatan penelitian yang dilakukan dalam bentuk kalimat, kata, atau gambar terhadap data lainnya untuk mendapat penjelasan terhadap suatu kebenaran atau sebaliknya, sehingga memperoleh gambaran baru ataupun menguatkan suatu gambaran yang ada (Mulyana, 2008). Pendekatan kualitatif digunakan untuk mendapatkan data mengenai aktivitas belajar dan keterlaksanaan pembelajaran siswa melalui observasi.

c. Pendekatan kuantitatif

Pendekatan kuantitatif merupakan pendekatan penelitian yang memperoleh data dalam bentuk jumlah kemudian untuk menjelaskan suatu kejelasan dari angka-angka untuk membandingkan dari beberapa gambaran sehingga memperoleh gambaran baru, kemudian dijelaskan kembali dalam bentuk kalimat (Arikunto, 2010). Sedangkan menurut Sugiyono (2009), pendekatan kuantitatif adalah suatu pendekatan yang berbentuk angka atau data kuantitatif yang diangkakan (skoring). Pendekatan kuantitatif dalam penelitian ini digunakan untuk mendapatkan data mengenai Prestasi Belajar siswa pada materi pelajaran dalam bentuk nilai yang diperoleh siswa pada setiap ujian pada akhir siklus.

\section{Instrumen Penelitian}

Instrumen adalah alat ukur yang digunakan untuk mengukur dalam rangka pengumpulan data. Dalam pendidikan, instrumen alat ukur yang digunakan untuk mengumpulkan data dapat berupa tes maupun nontes (Purwanto, 2010).

Instrumen yang digunakan dalam penelitian ini adalah :

1. Lembar observasi

Untuk mengetahui proses pembelajaran dengan penerapan pembelajaran PAIKEM dan dilakukan pengamatan terhadap aktivitas belajar dan pengamatan terhadap keterlaksanaan pembelajaran. Pengamatan dilakukan dengan mengamati kelas setiap siklus dan dibantu oleh satu orang guru yaitu guru MATEMATIKA yang ada di tempat penelitian. Isi lembar observasi adalah berisi tentang daftar pertanyaan baik untuk guru maupun untuk siswa.

2. Soal tes

Soal tes diberikan pada akhir penyampaian materi, untuk mengetahui Prestasi Belajar siswa. Tes dilakukan setiap akhir siklus belajar mengajar berlangsung dan pada akhir seluruh siklus. Jenis tes yang digunakan adalah tes obyektif atau pilihan ganda dan jumlah tes berjumlah 20 soal yang dikutip dari buku SMP/MTs kelas VIII.

\section{Teknik Pengumpulan Data}

Pengumpulan data dilakukan guna mendapatkan data yang tepat dan akurat yang sesuai dengan kebutuhan peneliti yang tepat dalam penelitian ini. Pada penelitian ini teknik pengumpulan data yang digunakan adalah :

1. Tes

Tes adalah serentetan pertanyaan atau latihan yang digunakan untuk mengukur keterampilan, dan pengetahuan intelegensi yang dimiliki oleh individu atau kelompok (Arikunto, 2010). Tes ini digunakan untuk mengetahui tingkat pemahaman dalam mengetahui materi yang disampaikan (Prestasi Belajar). 


\section{Observasi}

Observasi merupakan teknik pengumpulan data dengan cara mengamati setiap kejadian yang sedang berlangsung dan mencatatnya dengan alat observasi tentang hal-hal yang akan diamati atau diteliti (Sanjaya, 2009). Data tentang keterlaksanaan KBM (Kegiatan Belajar Mengajar) diperoleh melalui observasi.

\section{Teknik Analisis Data}

1. Lembar Observasi Aktivitas Belajar

Data mengenai ketercapaian Sistem Belajar PAIKEM dalam meningkatkan aktivitas dan Prestasi Belajar matematika yang berupa kata-kata kualitatif selanjutnya disajikan dalam bentuk kuantitatif agar dapat dianalisis secara persen yang dimaksud:

$P=\frac{\sum X}{n} x 100 \%$ (Arikunto, 2008)

Keterangan :

$\mathrm{P}=$ Persentase aktivitas belajar siswa

$\sum X \quad=$ Skor yang diperoleh

$n \quad=$ Skor maksimal

Tabel 2. Kategori Aktivitas Belajar Siswa Kelas VIII

\begin{tabular}{|c|c|c|}
\hline No. & Persentase & Kategori \\
\hline 1. & $80-100 \%$ & Sangat Aktif \\
\hline 2. & $69-79 \%$ & Aktif \\
\hline 3. & $40-59 \%$ & Cukup Aktif \\
\hline 4. & $20-39 \%$ & Kurang Aktif \\
\hline 5. & $0-19 \%$ & Pasif \\
\hline
\end{tabular}

2. Prestasi Belajar Siswa

Setelah memperoleh data Prestasi Belajar siswa, maka data tersebut kemudian dianalisis secara kuantitatif.

a. Ketuntasan Individu

Setiap siswa dalam proses belajar mengajar dikatakan tuntas terhadap materi pembelajaran yang diberikan apabila memperoleh nilai $\geq 70$ sesuai dengan KKM di sekolah tersebut.

Untuk mengetahui kekuntasan individu, maka dianalisis dengan menggunakan rumus sebagai berikut :

$\mathrm{N}=\frac{\mathrm{T}}{\mathrm{Tt}} \times 100$

Keterangan :

$\mathrm{N}=$ Nilai siswa

$\mathrm{T}=$ Skor yang diperoleh siswa

$\mathrm{Tt}=$ Jumlah total skor

$100=$ Skala nilai

(Purwanto dalam Purwakanti, 2010)

b. Ketuntasan Klasikal

Untuk mengetahui ketuntasan siswa secara klasikal dianalisis dengan menggunakan rumus : 
$K K=\frac{X}{Z} x 100 \%$ (Arikunto dalam Purwakanti, 2010)

Keterangan :

$K K=$ Ketuntasan Klasikal

$X=$ Jumlah siswa yang memperoleh nilai $\geq 70$

$Z \quad$ = Jumlah seluruh siswa

Suatu kelas dikatakan tuntas belajarnya jika di kelas tersebut terdapat $\geq$ 85\% siswa telah mencapai ketuntasan individual, untuk mengetahui kondisi ini, maka perlu dicari inovasi pembelajaran yang dirasakan cocok untuk merealisasikan tuntutan KTSP. Karena menurut (Sudjana, 2002), media pembelajaran dapat mempertinggi proses belajar siswa yang dicapai sesuai dengan standar nilai yang ditetapkan dalam Musyawarah Guru Mata Pelajaran (MGMP) oleh sekolah untuk mencapai tujuan tersebut.

\section{HASIL DAN PEMBAHASAN}

\section{Hasil Penelitian}

Penelitian ini dilaksanakan pada bulan Januari 2010 pada siswa kelas VIII.4 yang terdiri dari 36 siswa, dan dilaksanakan melalui dua siklus. Dari hasil penelitian yang dilaksanakan untuk setiap siklus diperoleh berbagai data kualitatif dan kuantitatif hasil penelitian yang telah dilakukan dan diuraikan hasilnya sebagai berikut :

a. Observasi Aktivitas Belajar Mengajar

Tabel 3. Data Hasil Aktivitas Siswa Kelas VIII.4 Siklus I dan Siklus II di SMPN 1 Kediri Tahun Pelajaran 2010/2011.

\begin{tabular}{|c|c|c|c|}
\hline \multirow{2}{*}{ No } & \multirow{2}{*}{ Indikator } & \multicolumn{2}{|c|}{ Skor } \\
\cline { 3 - 4 } & 1 & Siklus I & Siklus II \\
\hline 1 & 2 & 3 & 5 \\
\hline 2 & 3 & 3 & 4 \\
\hline 3 & 4 & 3 & 5 \\
\hline 4 & 5 & 2 & 3 \\
\hline 5 & 3 & 5 \\
\hline Total skor & 14 & 22 \\
\hline Persentase & $56 \%$ & $88 \%$ \\
\hline Kategori & Cukup aktif & Sangat Aktif \\
\hline
\end{tabular}

Tabel 4. Aktivitas Kegiatan Belajar Mengajar Guru Siklus I dan Siklu II di SMPN 1 Kediri Tahun Pelajaran 2010/2011.

\begin{tabular}{|l|c|c|}
\hline \multirow{2}{*}{\multicolumn{1}{|c|}{ spek yang di observasi }} & \multicolumn{2}{c|}{ Hasil } \\
\cline { 2 - 3 } & Siklus I & Siklus II \\
\hline $\begin{array}{l}\text { 12 Aspek yang di teliti dari setiap } \\
\text { siklus yang Nampak }\end{array}$ & 9 & 12 \\
\hline Total skor & 9 & 12 \\
\hline Persentase & $75 \%$ & $100 \%$ \\
\hline Kategori & Baik & Sangat Baik \\
\hline
\end{tabular}




\section{b. Hasil Refleksi}

Tabel 5. Tabel Hasil Refleksi Pelaksanaan Tindakan Pada Siklus I Serta Perbaikan Pada Siklus II.

\begin{tabular}{|c|c|c|}
\hline No & Tindakan pada siklus I & Perbaikan pada siklus II \\
\hline 1 & $\begin{array}{l}\text { Siswa kurang memperhatikan } \\
\text { dengan seksama selama proses } \\
\text { belajar mengajar berlangsung }\end{array}$ & $\begin{array}{l}\text { Guru mengarahkan siswa agar } \\
\text { lebih memperhatikan dengan } \\
\text { seksama selama proses belajar } \\
\text { mengajar berlangsung }\end{array}$ \\
\hline 2 & $\begin{array}{l}\text { Siswa kurang memiliki tanggung } \\
\text { jawab terhadap kelompoknya }\end{array}$ & $\begin{array}{l}\text { Guru harus menegaskan arti } \\
\text { pentingnya pembagian tugas } \\
\text { dalam masing-masing anggota } \\
\text { agar semua anggota dapat } \\
\text { memiliki rasa tanggung jawab } \\
\text { yang sama terhadap kelompoknya }\end{array}$ \\
\hline 3 & $\begin{array}{l}\text { Siswa tidak mengemukakan } \\
\text { pendapatnya terhadap kelompok } \\
\text { sendiri }\end{array}$ & $\begin{array}{l}\text { Guru harus aktif mendampingi } \\
\text { siswa dan memfasilitas kegiatan } \\
\text { kelompok yang masih kurang } \\
\text { pemahamannya }\end{array}$ \\
\hline 4 & $\begin{array}{l}\text { Siswa tidak mengajukan pertanyaan } \\
\text { terhadap hal-hal yang belum jelas }\end{array}$ & $\begin{array}{l}\text { Guru harus bisa mengaitkan materi } \\
\text { sebelumnya dengan materi yang } \\
\text { akan diajarkan }\end{array}$ \\
\hline 5 & $\begin{array}{l}\text { Siwa tidak berusaha untuk } \\
\text { menjawab pertanyaan yang diajukan } \\
\text { oleh guru }\end{array}$ & $\begin{array}{l}\text { Guru harus mampu membangun } \\
\text { komunikasi yang interaktif dengan } \\
\text { siswa dalam proses pembelajaran }\end{array}$ \\
\hline 6 & engemukakan & $\begin{array}{l}\text { Guru harus bisa memotivasi dan } \\
\text { member dorongan serta } \\
\text { semangatkepada siswa untuk tidak } \\
\text { malu bertanya }\end{array}$ \\
\hline 7 & n lain & $\begin{array}{l}\text { untuk lebih } \\
\text { an }\end{array}$ \\
\hline 8 & $\begin{array}{l}\text { Siswa belum mampu mengambil dan } \\
\text { mencatat sendiri apa yang di } \\
\text { diskusikan dalam belajar kolaboratif } \\
\text { sistem PAIKEM }\end{array}$ & $\begin{array}{l}\text { Guru mengarahkan siswa untuk } \\
\text { menambah kesimpulan }\end{array}$ \\
\hline 9 & nggapi pendapat & $\begin{array}{l}\text { Guru mengarahkan siswa agar } \\
\text { berani mengemukakan pendapat }\end{array}$ \\
\hline 10 & $\begin{array}{l}\text { Siswa tidak membuat rangkuman } \\
\text { yang diberikan oleh guru }\end{array}$ & $\begin{array}{l}\text { Guru meminta siswa untuk } \\
\text { membuat rangkuman. }\end{array}$ \\
\hline 11 & $\begin{array}{l}\text { Hasil evaluasi belajar siswa belum } \\
\text { mencapai ketuntasan }\end{array}$ & $\begin{array}{l}\text { Guru berupaya memaksimalkan } \\
\text { kegiatan pembelajaran dikelas }\end{array}$ \\
\hline 12 & $\begin{array}{l}\text { Guru tidak men } \\
\text { materi pembelajar }\end{array}$ & $\begin{array}{l}\text { Guru menyampaikan tujuan materi } \\
\text { pembelajaran dikelas }\end{array}$ \\
\hline 13 & $\begin{array}{l}\text { Guru tidak mengkaitkan materi } \\
\text { pelajaran yang akan dibahas dengan }\end{array}$ & $\begin{array}{ll}\text { Guru } & \text { mengkaitkan } \\
\text { pelajaran } & \text { yang }\end{array}$ \\
\hline
\end{tabular}




\begin{tabular}{|c|c|c|}
\hline & materi pembelajaran & dengan materi pembelajaran \\
\hline 14 & $\begin{array}{l}\text { Guru tidak memberi informasi } \\
\text { kepada siswa selanjutnya melakukan } \\
\text { refleksi terhadap materi yang } \\
\text { disampaikan }\end{array}$ & $\begin{array}{l}\text { Guru memberi informasi kepada } \\
\text { siswa selanjutnya melakukan } \\
\text { refleksi terhadap materi yang } \\
\text { disampaikan }\end{array}$ \\
\hline
\end{tabular}

c. Hasil Evaluasi Belajar Siswa

Tabel 6. Hasil Evaluasi Belajar Siswa Kelas VIII.4 Siklus I dan Siklus II di SMPN 1 Kediri Tahun Pelajaran 2010/2011.

\begin{tabular}{|c|l|c|c|}
\hline No & \multicolumn{1}{|c|}{ Aspek } & Siklus I & Siklus II \\
\hline 1 & Jumlah siswa keseluruhan & 36 & 36 \\
\hline 2 & Jumlah siswa yang ikut tes & 36 & 36 \\
\hline 3 & Jumlah siswa yang tuntas & 9 & 31 \\
\hline 4 & Jumlah siswa yang tidak tuntas & 27 & 5 \\
\hline 5 & Nilai rata-rata kelas & $55 \%$ & $77 \%$ \\
\hline 6 & Persentase ketuntasan klasikal (\%) & $25 \%$ & $86 \%$ \\
\hline
\end{tabular}

\section{Pembahasan}

Penelitian Tindakan Kelas ini dilakukan dalam dua siklus dengan menggunakan pendekatan belajar PAIKEM pada pokok bahasan Sistem Pencernaan Pada Manusia. Penelitian ini menggunakan prosedur Penelitian Tindakan Kelas (PTK) yang telah ditetapkan yaitu tahap perencanaan, pelaksanaan tindakan, observasi dan refleksi. Pada siklus I tahap perencanaan dilakukan persiapanpersiapan untuk melakukan pembelajaran seperti membuat Rencana Pelaksanaan Pembelajaran (RPP) menyiapkan lembar observasi dan membuat alat evaluasi. Penelitian Tindakan Kelas ini kemudian dilanjutkan pada tahap tindakan dilakukan pada dua siklus. Adapun langkah-langkah pembelajaran tertuang dalam skenario pembelajaran.

\section{Hasil Aktivitas Belajar Siswa}

Dalam kegiatan belajar mengajar, guru sangat berperan dalam aktivitas belajar siswa karena aktivitas merupakan prinsip atau asas yang sangat penting dalam interaksi belajar mengajar. Menurut Sardiman (2002), mengatakan bahwa yang lebih banyak melakukan aktivitas di dalam pembentukan diri adalah anak itu sendiri, sedangkan guru memberikan bimbingan dan merencanakan segala kegiatan yang akan diperbuat oleh siswa. Sedangkan menurut Slavin (2001), menjelaskan bahwa setiap orang yang ingin belajar harus aktif sendiri, tanpa adanya aktivitas maka proses belajar tidak mungkin terjadi.

Dengan menerapkan pembelajaran model PAIKEM aktivitas siswa dapat meningkat, karena belajar menggunakan PAIKEM adalah suatu metode belajar yang menekankan bahwa interaksi dengan orang lain untuk memecahkan berbagai kesulitan dalam belajar adalah bagian terpenting dalam meningkatkan aktivitas dan prestasi belajar siswa. Berdasarkan hasil analisis data aktivitas belajar siswa pada siklus I tergolong cukup aktif dengan skor 14 dengan persentase keaktifan $56 \%$ ini tergolong dalam kategori cukup aktif. Sedangkan pada siklus II terdapat peningkatan 
aktivitas dengan skor 22 persentase keaktifan $88 \%$. Peningkatan aktifitas siswa dari siklus I ke siklus II juga disebabkan karena metode yang di pakai dalam pembelajaran yaitu dengan belajar sistem PAIKEM yang dapat memudahkan siswa untuk mengomunikasikan gagasan-gagasannya, serta interaksi dalam belajar yang terjadi antara guru dan siswa sangat aktif.

Dengan menerapkan model pembelajaran PAIKEM aktivitas belajar siswa dapat meningkat, karena belajar menggunakan model PAIKEM adalah suatu metode belajar yang menekankan bahwa interaksi dengan orang lain untuk memecahkan berbagai kesulitan dalam belajar adalah bagian terpenting dalam meningkatkan aktivitas dan prestasi belajar siswa.

\section{Hasil Aktivitas Belajar Mengajar Guru}

Berdasarkan hasil analisis data aktivitas belajar mengajar guru pada siklus I dengan total skor 9 dengan persentase keaktifan $75 \%$ ini tergolong dalam kategori aktif. Hal ini terjadi karena beberapa hal diantaranya yaitu guru tidak menyampaikan tujuan materi pelajaran dikelas, guru tidak mengkaitkan materi pelajaran yang akan dibahas dengan materi pembelajaran dan guru tidak memberi informasi kepada siswa selanjutnya melakukan repleksi terhadap materi yang disampaikan, sehingga perlu dilakukan refleksi pada siklus II.

Adapun tindakan yang dilakukan pada siklus II prinsipnya sama pada siklus sebelumnya. Namun pada siklus II dilakukan refleksi terhadap kekurangankekurangan pada siklus I diantaranya guru menyampaikan tujuan pembelajaran, guru mengaitkan materi pelajaran yang akan dibahas dengan materi pembelajaran dan guru memberi informasi kepada siswa selanjutnya melakukan repleksi terhadap materi yang disampaikan.

Setelah refleksi dilakukan ternyata hasil aktivitas belajar guru pada siklus II mengalami peningkatan aktivitas dengan total skor 12 dengan persentase keaktifan $100 \%$. Hal ini di karenakan langkah-langkah penerapan strategi pembelajaran PAIKEM berjalan dengan baik sehingga mendapatkan hasil yang maksimal.

\section{Hasil Evaluasi Belajar Siswa}

Setelah proses belajar mengajar menggunakan metode pendekatan sistem pembelajaran PAIKEM ternyata hasil evaluasi pada siklus I menunjukan persentase ketuntasan $25 \%$. Secara klasikal ketuntasan belajar siswa pada siklus I belum tuntas karena pencapaian hasil ketuntasan belajar kurang dari 85\%. Hal tersebut disebabkan karena siswa masih belum terbiasa dengan model pembelajaran yang digunakan, siswa kurang memperhatikan pelajaran dengan seksama, siswa belum memiliki tanggung jawab dalam kelompoknya, siswa tidak berani untuk mengajukan pertanyaan kepada gurunya berkaitan dengan materi pelajaran yang belum jelas, siswa tidak menanggapi setiap pertanyaan yang diberikan oleh guru dan siswa tidak membuat rangkuman yang diberikan oleh guru. Berdasarkan dari hasil siklus I maka dilakukan penyempurnaan pada siklus II dengan cara memperbaiki kekurangan pada siklus I.

Adapun tindakan yang dilakukan pada siklus II pada prinsipnya sama dengan siklus sebelumnya. Berdasarkan dari hasil siklus I maka dilakukan penyempurnaan pada siklus II dengan cara memperbaiki kekurangan-kekurangan pada siklus I yaitu antara lain dengan cara meminta siswa untuk lebih serius dan memperhatikan 
pelajaran dengan seksama agar siswa dapat mencapai hasil yang lebih maksimal dan siswa sudah mulai terbiasa dengan model pembelajaran yang digunkan.

Setelah refleksi pada siklus II siswa memperoleh hasil yang lebih baik. Ini ditunjukkan dari hasil evaluasi siklus II dimana persentase ketuntasan klasikalnya sebesar $86 \%$ yang berarti prestasi belajar siswa telah tuntas.

Keuntungan dari penerapan model pembelajaran PAIKEM yaitu guru lebih mudah menarik minat serta semangat belajar siswa karena siswa lebih senang berinteraksi langsung dengan siswa dan guru itu sendiri dalam belajar di dalam kelas. Dari proses tindakan dan hasil yang diperoleh pada siklus I dan siklus II, menunjukkan hasil yang sangat bagus. Berarti penerapan pembelajaran model PAIKEM dapat meningkatkan aktivitas dan prestasi belajar siswa khususnya pada pelajaran Matematika.

\section{KESIMPULAN}

Berdasarkan hasil penelitian yang diperoleh, dapat disimpulkan bahwa penerapan pembelajaran berbasis PAIKEM dapat meningkatkan aktivitas dan prestasi belajar Matematika pada siswa kelas VIII SMPN 1 Kediri Tahun Pelajaran 2010/2011. Hal ini dapat dilihat dari aktivitas kegiatan belajar mengajar guru pada siklus I dengan persentase $75 \%$ masuk dalam kategori baik dan pada siklus II dengan persentase $100 \%$ masuk dalam kategori sangat baik. Sedangkan data hasil aktivitas siswa pada siklus I dengan persentse 56\% masuk dalam kategori cukup aktif dan pada siklus II dengan persentase $88 \%$ dengan kategori sangat aktif. Dari hasil evaluasi belajar siswa pada siklus I dengan persentase ketuntasan klasikal 25\% dan ada peningkatan pada siklus II dengan persentase ketuntasan klasikal $86 \%$.

Saran dan tindak lamjut dari hesil penelitian ini adalah 1) Dalam proses belajar mengajar hendaknya menggunakan metode sesuai dengan materi yang akan disampaikan agar siswa tidak cepat merasa bosan dalam mengikuti pelajaran; 2) Hasil penelitian ini diharapkan dapat digunakan sebagai bahan pertimbangan bagi guru dalam upaya meningkatkan prestasi belajar siswa khususnya pada pokok bahasan sistem pencernaan pada manusia dan mata pelajaran matematika pada umumnya; 3) Bagi peneliti selanjutnya yang ingin melanjutkan penelitian tentang PAIKEM diharapkan agar dapat menerapkan model pembelajaran ini pada pokok bahasan atau mata pelajaran yang lain dan juga hendaknya dapat mempertimbangkan serta memperhitungkan faktor-faktor lain yang kemungkinan dapat mempengaruhi hasil peneliti sehingga kekurangan-kekurangan yang ada pada peneliti ini dapat disempurnakan.

\section{DAFTAR PUSTAKA}

Anom, DK. (2011). Meningkatkan Prestasi Belajar IPA dengan Pendekatan Paikem Pada Kelas V SD Negeri 4 Mambalan Tahun Pelajaran 2010/2011. Universitas Mataram.

Arikunto. (2005). Dasar-Dasar Evaluasi Pendidikan. Jakarta : Bumi Aksara.

Arikunto. (2008 ). Penelitian Tindakan Kelas. Jakarta : Bumi Aksara. 
Arikunto. (2010), Prosedur Penelitian Suatu Pendekatan Praktik Edis Revisi. Jakarta : Rineka Cipta.

Depdiknas. (2003). Dasar-Dasar Evaluasi Pendidikan. Jakarta : Bumi Aksara.

Hamalik. (2004). Fsikologi Belajar Mengajar. Bandung : Sinar Baru Grasindo.

Hamzah. (2002). Metodologi Pembelajaran di Kelas. Bandung : Sinar Baru.

Mulyana. (2008). Metodologi Penelitian Kualitatif. Bandung : Remaja Rosda Karya.

Nasir, (1999). Penelitian Tindakan Kelas. Jakarta : Rineka Cipta.

Purwakanti. (2010). Penerapan Model Pembelajaran Kolaboratif MURDER Dalam Meningkatkan Aktivitas Belajar Dan Hasil Belajar Matematika Slameto, 2003. Belajar dan Faktor-faktor Yang Mempengaruhinya. Jakarta : Rineka Cipta.

Purwanto. (2010). Evaluasi Hasi Belajar. Yogyakarta : Pustaka Pelajar.

Sanjaya. (2009). Penelitian dan Penilaian Pendidikan. Jakarta : Sinar Baru.

Santyasa, (2006). Metodologi Penelitian Tindakan Kelas. Singaraja: Universitas PendididkanGanesha. (UG press).

Sardiman, (2002). Konsep dan Makna Pembelajaran. Bandung : Alfabeta.

Slameto. (2003). Belajar dan Faktor-Faktor Yang Mempengaruhinya. Jakarta: Asdi Mahasatya.

Slameto. (2010). Belajar dan Faktor-Faktor Yang Mempengaruhinya. Jakarta: Rineke Cipta.

Slavin, TG. (2001). Action research : Collecting and analyzing data. http://www.nipissngu.ca.oar/Reports/reports and document - Thomas G Ryan\%20.pdf

Sudjana. (2002). Dasar-Dasar Proses Belajar Mengajar. Bandung : Sinar Baru Algesindo.

Sudjana. (2011). Dasar-Dasar Proses Belajar Mengajar. Bandung : Sinar Baru Algesindo.

Suprijono, A. (2011). Cooperative Learning. Yogyakarta : Pustaka Belajar.

Suryabrata, S. (2004). Metodologi Penelitian. Jakarta: Raja Grapindo Prasada 